\title{
Attitudes of Music Teacher Candidates for Non-Field Courses
}

\author{
Mustafa Kabataş \\ Correspondence: Mustafa Kabataş, Kastamonu Üniversitesi Eğitim Fakültesi Güzel Sanatlar Eğitimi Bölümü Müzik \\ Eğitimi Anabilim Dalı, Turkey.
}

Received: May 4, 2020 Accepted: June 14, 2020 Online Published: June 15, 2020

doi:10.11114/jets.v8i7.4835

URL: https://doi.org/10.11114/jets.v8i7.4835

\begin{abstract}
People dealing with music do not usually deal with other fields. Artist spirits do not allow for this reason; Music teacher candidates have difficulty in non-music lessons during their student years. The subject of this study is why non-field courses force them, how they will succeed and how they will achieve it. This research; It aims to determine how students of the Faculty of Education, Department of Fine Arts Education, Department of Music Education, view their perspectives on courses outside the field. Research; It was applied over 43 students of Kastamonu University Faculty of Education Fine Arts Education Department Music Education Department students. Likert type attitude scale was used while collecting the research data. The data obtained from the research is transferred in the findings section. The data obtained are discussed in the results and recommendations section. Research is important in terms of contributing to music education faculty students, academicians and music field experts.
\end{abstract}

Keywords: music, education, music education, fine arts education, out-of-field education

\section{Introduction}

Turkey from 26 different universities in the Faculty of Education, Fine Arts Education Department Music Education Department at 600 to close the student is studying. The readiness of students for field courses can be measured in the aptitude exams, but non-field courses challenge students both in reading and in their professional life. The main task of the music teacher creates permanent track behavior change in students in line with the goals of the school and the lessons. In order for the music teacher to fulfill this task, he / she should have both the subject area information required for the acquisition of the objectives and the teaching profession knowledge that will provide the environmental arrangement that will create valid learning experiences. It is very difficult to obtain the desired efficiency from the teacher who lacks one of these two different fields of behavior (Bloom, S. B. et. al., 1976). The pre-service teachers who study at the Department of Music Education at the Faculty of Education, Department of Fine Arts Education acquire basic behaviors related to the teaching profession through out-of-field lessons in the Department of Music Education given by the Education Faculties. Although these courses are one of the most important elements that prepare prospective teachers for the teaching profession, it is observed that the students do not attach importance to these courses and participate reluctantly. However, the researches show that there is a significant relationship between students' affective characteristics and academic achievements, and students with positive affective characteristics are more successful in the courses (Munure, E. et. al., 1995). One of the most important indicators of the affective characteristics of students about a course is their attitude. Attitude is a tendency that organizes the individual's thoughts, feelings and behaviors about objects, ideas, institutions, events and other people. It belongs to the individual and ensures that the individual is consistent in his feelings, thoughts and behaviors (İlter, et. al., Ç. 2012). For this reason, if the student likes out-of-field lessons in the Department of Music Education given by the Faculties of Education, these lessons are expected to be successful. Attitude has 3 dimensions: cognitive, emotional and behavioral, and these dimensions are in a consistent relationship with each other. These three dimensions, which interact with each other, are not evaluated with strictly separate lines. For example; If we have a positive attitude towards a team, we go to the matches of that team, we love the colors of that team, we are happy for the success of that team. Although the attitudes of the music department students towards a certain lesson play an important role in student success, it is very difficult to create an attitude towards a certain object in the individual and to change the existing attitude. In order to change the attitudes of students, first of all, the factors that cause the development and attitudes of the target audience and the factors that need to be developed should be revealed (Münre, E. et. al., 1995). Researches conducted in our country show that the majority of the parents who attend educational institutions that train teachers have low education level (Çelenk, S. et. al., 1988). These families may have different reasons for their children choosing the teaching profession. However, the data obtained can be interpreted as the attitudes of these families towards 
teaching profession are more positive. Because the families with low education level generally have low income levels, the teaching profession can also increase the social mobility of the children of these families. However, families with high education and income levels may not want their children to become teachers because the teaching profession will decrease or not change the social status of their children (Münre, E. et. al., 1995). The main aim of this research is to determine some factors that affect the attitudes and attitudes of music teacher candidates towards non-teaching subjects based on the above information. For this purpose, answers to the following questions were sought.

1. Do the attitudes of music teacher candidates towards extra-curricular courses change according to their gender?

2. Does the attitude of music teacher candidates towards extra-curricular courses change according to the education level of their families?

3. Do the attitudes of music teacher candidates towards non-field courses change according to the education level in the field courses?

4. Do the attitudes of music teacher candidates towards extra-curricular courses change according to their individual instruments?

5. Do the attitudes of music teacher candidates towards extra-curricular courses change according to their desire to become teachers?

\section{Methods}

Survey research method was used to determine what the attitudes of music teacher candidates towards out-of-field courses were determined.

\subsection{Universe and Sampling}

43 pre-service teachers studying at Kastamonu University Faculty of Education Fine Arts Education Department Music Education Department constituted the universe of the research. While applying the measurement tools, it is assumed that the music teacher candidates fill the measurement tools completely and completely.

\subsection{Data Collection Tools}

While collecting the data in the research, a questionnaire form was used to determine the attitudes and personal characteristics of the music teacher candidates from the Department of Music Education, Faculty of Education, Department of Music Education. The attitudes of music teacher candidates towards extra-curricular courses were measured by Likert type scale developed by the researcher. There are 10 attitude sentences evaluated equally on the Likert type scale developed by the researcher. While answering the questions, the music teacher candidates stated that they completely agree, agree, undecided, disagree, disagree completely. Alpha internal consistency coefficient of the scale was calculated as $83 \%$.

\subsection{Data Analysis}

While analyzing the data in the study, the answers of a questionnaire that consists of questions that determine the tufts and personal characteristics of the music teacher candidates from the Department of Music Education, Faculty of Education, Department of Music Education were also taken. Music teacher candidates' answers were scored from 5 to 1 . The highest score that can be obtained from the created Likert scale is 50 and the lowest score is 10 . After the attitude scores of the music teacher candidates were calculated, $t$ test or one-way analysis of variance was applied according to the research problem.

\section{Findings}

The findings and comments obtained in the research are given below as a result of the answers to the 5 questions that form the problem of the research.

\subsection{Do the Attitudes of Music Teacher Candidates Towards Extra-Curricular Courses Change According to Their Gender?}

Do the attitudes of music teacher candidates towards extra-curricular courses change according to their gender? In the answers we received to the question, firstly, the music divided the teacher candidates into two groups according to their gender. The average scores of the created groups were compared with the $t$ test. The $t$ test was found to be $t(43)=1.287$ as a result of statistical analysis. This value was not statistically significant at the level of $\mathrm{P}<0.5$. Considering the results, no distinction was found between the pre-service teachers of the music teachers against their lessons in terms of their gender. Looking at Table 1 of the music teacher candidates who responded to the research, $68.8 \%$ of the teacher candidates are girls and $31.2 \%$ are boys. When the average of attitude scores of teacher candidates for teacher certification courses according to their gender is analyzed, it is seen that the average of attitude scores of male music teacher candidates (37.4) is higher than the average of the attitude scores of female teacher candidates (35.7). However, the difference between 
them is not statistically significant. The attitudes of both groups towards out-of-field courses are among the categories "I am indecisive" and "I agree".

Table 1. Average and Standard Deviations of the Attitudes Scores of Music Teacher Candidates to Out of Class Classes by Gender

\begin{tabular}{lllll}
\hline Gender & $\mathbf{N}$ & $\boldsymbol{\%}$ & $\mathbf{X}$ & $\mathbf{S}$ \\
\hline Woman & 29 & 68.8 & 35.7 & 7.57 \\
Man & 14 & 31.2 & 37.4 & 7.87 \\
\hline
\end{tabular}

$\mathrm{N}$ : Number,\%: Percentage, X: Attitude, S: Standard Deviation

Based on these findings of the research, it can be said that the attitudes of music teacher candidates towards out-of-field lessons are also affected by factors other than gender.

3.2 Does the Attitude of Music Teacher Candidates Towards Extra-Curricular Courses Change According to the Educational Status of Their Families?

Do the attitudes of music teacher candidates towards extra-curricular courses change according to the education level of their families? While seeking the answers to the question, the candidate music teacher candidates were primarily grouped according to my families education groups. Letters were used when grouping the educational status of families. It was grouped as E who never went to school, A who went to primary school, B who went to secondary school, C who went to high school, D who went to university. The average and standard deviations of the attitudes scores of the music teacher candidates towards out-of-field lessons were calculated according to the educational status of their families.

Table 2. Average and Standard Deviations of the Attitudes Scores of Music Teacher Candidates to Out of Field Courses According to Their Education Status

\begin{tabular}{lllll}
\hline $\begin{array}{l}\text { Education } \\
\text { Status }\end{array}$ & $\mathbf{N}$ & $\boldsymbol{\%}$ & $\mathbf{X}$ & $\mathbf{S}$ \\
\hline $\mathbf{A}$ & 19 & 42.3 & 36.2 & 8.1 \\
$\mathbf{B}$ & 8 & 18.6 & 32.78 & 9.4 \\
$\mathbf{C}$ & 11 & 26.5 & 36.16 & 6.2 \\
$\mathbf{D}$ & 5 & 12.6 & 32.73 & 7.1 \\
\hline
\end{tabular}

N: Number,\%: Percentage, X: Attitude, S: Standard Deviation

Based on these findings of the study, it can be said that the education status of the music teacher candidates is quite low. Approximately $42.3 \%$ of the music teacher candidates went to primary school, $18.6 \%$ went to secondary school, $26.5 \%$ went to high school and $12.6 \%$ went to university. When the average of the attitude scores of the music teacher candidates for out-of-field lessons according to the educational status of the families is examined, it is seen that the average of the attitude scores of the high school and primary school graduate mothers' children is about 36 and about 32 in the other groups. One-way analysis of variance was conducted to check the statistical significance of the difference between the attitude scores of the music teacher candidates' families according to their educational status. The results of the analysis are summarized in Table 3. As seen in Table 3, F value as a result of analysis. It has been calculated as 764. This value was not statistically significant for $\mathrm{p}<.05$. Do the attitudes of music teacher candidates towards extra-curricular courses change according to the education level of their families? Looking at the answer to the question, it seems that the attitudes of music teacher candidates towards out-of-field lessons do not change according to the education level of their families.

Table 3. Variance Analysis Results of Attitude Points of Music Teacher Candidates towards Out of Field Courses According to the Educational Status of Families

\begin{tabular}{lllll}
\hline $\begin{array}{l}\text { Variance } \\
\text { Source }\end{array}$ & KT & SD & KO & F \\
\hline $\begin{array}{l}\text { Education } \\
\begin{array}{l}\text { Status of } \\
\text { the Family }\end{array}\end{array}$ & 189.257 & 4 & 47.654 & \\
Mistake & 10647.257 & 159 & 63.569 & \\
Total & 10956.105 & 161 & & \\
\hline
\end{tabular}

Variant Analysis Values: KT, SD, KO, F 
Based on these findings, it can be said that the attitudes of music teacher candidates towards extra-curricular courses are influenced by factors other than their families' educational status.

3.3 Do the Attitudes of Music Teacher Candidates Towards Non-Field Courses Change According to the Education Level in the Field Courses?

Do the attitudes of music teacher candidates towards non-field courses change according to the education level in the field courses? While looking for an answer to the question, we asked the pre-service teachers who thought that the effects of the field lessons on the tufts of the non-field lessons had been grouped and A was not fully disagree, B disagree, C partially agree, D agree, E totally agree. The average and standard deviations of the attitude points of the changes in the attitudes of the candidates of the music teacher towards the non-field courses according to the educational status in the field courses were calculated.

Table 4: Attitudes of Music Teacher Candidates towards Field Female Lessons Average and Standard Deviations of Attitude Points for Changes According to Educational Status in Field Streams

\begin{tabular}{lllll}
\hline $\begin{array}{l}\text { Group } \\
\text { Letters }\end{array}$ & N & \% & X & S \\
\hline A & 18 & 40.3 & 35.26 & 6.3 \\
B & 11 & 26.5 & 36.52 & 7.6 \\
C & 8 & 18.6 & 36.78 & 7.9 \\
D & 5 & 12.6 & 35.41 & 7.4 \\
E & 1 & 2.7 & 35.23 & 7.6 \\
\hline
\end{tabular}

N: Number,\%: Percentage, X: Attitude, S: Standard Deviation

As seen in Table 4, the average and standard deviation scores of the attitudes towards the changes in the attitudes towards the out-of-field courses of the music teacher candidates according to the education level in the field courses are shown. 18, I do not agree 11, I partially agree 8, I agree 5, I totally agree 1 person who says that I do not fully agree with the thought that the field courses of music teacher candidates affect out-of-field lessons. It is seen that the attitudes scores of the music teacher candidates towards out-of-field lessons according to the education level in the field courses are about 36 and the others about 35. One-way analysis of variance was conducted to check the statistical significance of the difference between the attitudes towards the changes in the attitudes towards the out-of-field lessons of the music teacher candidates according to the education level in the field courses. The results of the analysis are summarized in Table 5. As seen in Table 5, F value at the end of the analysis. It was calculated as 347. This value p. It was not statistically significant for 05 . In other words, the success of music teacher candidates in field courses does not contribute to the success of non-field courses.

Table 5. Attitudes of Music Teacher Candidates towards Out-of-Field Courses Variance Analysis Results of Attitude Points for Changes According to Educational Status in Field Courses

\begin{tabular}{lllll}
\hline $\begin{array}{l}\text { Variance } \\
\text { Source }\end{array}$ & KT & SD & KO & F \\
\hline $\begin{array}{llll}\text { Education } \\
\text { Status }\end{array}$ & 81.15 & 4 & 21.368 & \\
Mistake & 10458.457 & 159 & 68.247 & \\
Total & 10998.622 & 179 & & \\
\hline
\end{tabular}

Variant Analysis Values: KT, SD, KO, F

Looking at Table 5, we can say that the success of music teacher candidates in non-field courses affects other factors, not the success in courses.

\subsection{Do the Attitudes of Music Teacher Candidates Towards Extra-Curricular Courses Change According to Their} Individual Instruments?

Do the attitudes of music teacher candidates towards extra-curricular courses change according to their individual instruments? In order to search for the answer to the question, first of all, the pre-service music teacher candidates determined the individual instruments that were permanent as long as they studied in the school, and the average and standard deviation scores of each group were calculated. 
Table 6. Average and Standard Deviation of Attitudes Scores of Music Teacher Candidates towards the Change of Attitudes towards Candidate Teachers' Outside Classes According to Their Individual Instruments

\begin{tabular}{llll}
\hline $\begin{array}{l}\text { Individual } \\
\text { Instrument }\end{array}$ & $\mathbf{N}$ & $\mathbf{X}$ & $\mathbf{Z}$ \\
\hline Violin & 13 & 34.13 & 4.5 \\
Viola & 4 & 40.25 & 8.1 \\
Çello & 6 & 37.69 & 7.23 \\
Ud & 3 & 42.13 & 8.8 \\
Giutar & 7 & 36.42 & 6.32 \\
Bağlama & 10 & 35.25 & 5.28 \\
\hline
\end{tabular}

$\mathrm{N}$ : Number, X: Attitude, S: Standard Deviation

When we look at Table 6, it was seen that the individual instrument lessons were violin 34.13 , viola 40.25, cello 37.69, oud 42.13, guitar 36.42, binding 35.25. While the most positive individual instrument group takes oud with 42.13, it follows violas with 40.25 . The violin group with the lowest attitude score average is 34.13 . One-way analysis of variance was used to check the significance of the difference between music teacher candidates' individual instrument groups. The results of the analysis are shown in table 7.

Table 7. Variance Analysis of Music Teacher Candidates' Attitude Scores Results for Changing Their Attitudes towards Out of Field Courses According to Their Individual Instruments

\begin{tabular}{llllll}
\hline $\begin{array}{l}\text { Variance } \\
\text { Source }\end{array}$ & KT & SD & KO & F & P \\
\hline $\begin{array}{l}\text { Individual } \\
\text { Instrument }\end{array}$ & 2733.05 & 6 & 509.715 & 13.029 & 0.6 \\
$\begin{array}{l}\text { Mistake } \\
\text { Total }\end{array}$ & 8606.328 & 164 & 49.68 & & \\
\hline
\end{tabular}

Variant Analysis Values: KT, SD, KO, F, P

As seen in Table 7, variance analysis $F$ value was calculated as 13.029. This value was found significant at $\mathrm{p}<.05$ level. This shows that the attitudes of music teacher candidates towards extra-curricular courses vary according to their fields.

3.5 Do the Attitudes of Music Teacher Candidates Towards Extra-Curricular Courses Change According to Their Desire To Become Teachers?

Do the attitudes of music teacher candidates towards extra-curricular courses change according to their desire to become teachers? The answer to the question is a question that all the music teacher candidates who study at the Faculty of Education, Department of Fine Arts Education, and Music Teaching Department should answer. The question is why you chose the department of music teaching even in the aptitude tests. This is the answer of the students who have a great place in the lives of music to the teaching profession which is sacred. Do the music teacher candidates choose this profession willingly, and if they have a chance, do they want to do another profession? The mean and standard deviations of the attitude points created from the answers were calculated.

Table 8. Attitudes of Music Teacher Candidates towards Extra-Curricular Classes Average and Standard Deviations of Attitude Scores According to Their Request to Become Teachers

\begin{tabular}{lllll}
\hline & $\mathbf{N}$ & \% & $\mathbf{X}$ & $\mathbf{S}$ \\
\hline $\mathbf{A}$ & 39 & 89.7 & 38.85 & 6.45 \\
$\mathbf{B}$ & 4 & 10.3 & 32.41 & 9.27 \\
\hline
\end{tabular}

N: Number,\%: Percentage, X: Attitude, S: Standard Deviation

As it is seen in Table 8, 89.7\% of the music teacher candidates believe that music teaching is a suitable profession for them. On the other hand, $10,3 \%$ of the music teacher candidates want to work in a job other than music teaching related to their fields or not. The results show that prospective music teachers are largely eager to become music teachers. According to the wishes of music teacher candidates to become music teachers, $t$ test was used to check the significance of the difference between the averages of attitude scores towards out-of-field lessons. The result of the analysis was calculated as $t(172)=2.163$. This value was significant as $p<0.5$. The attitudes of music teacher candidates towards extra-curricular courses change according to their desire to become a music teacher. 


\section{Conclusion and Suggestions}

In the research, it was tried to determine the attitudes of the candidates of music teacher candidates towards out-of-field lessons, their gender, family educational status, success in field courses, differences in their individual instruments, and desire to become music teachers. According to the results of the research, the attitudes of music teacher candidates towards non-field courses do not change according to the gender of the candidates. We see that the perspective of music teaching, the old female profession has changed. Although it is a fact that the music talent comes from the family, the education status of the music teacher candidates' families does not change the attitudes of the music teacher candidates towards the courses outside the field. Interestingly, the differences in music teacher candidates' individual instruments have been a variable in the attitudes of music teacher candidates towards out-of-field lessons. The attitudes scores of the music teacher candidates, who are willing to become a music teacher, to the lessons outside the field were significantly higher than the attitude points of those who are not willing to be music teachers to the lessons outside the field. If we briefly summarize the information obtained in the research, we can see that the attitudes of music teacher candidates towards out-of-class lessons are more important than their personal characteristics and the quality education they receive is important. One of the most important elements of this research; Assessment of such studies, making the necessary physical and academic environments more suitable for giving more qualified out-of-field lessons taught in the Department of Music Education, Faculty of Education, Faculty of Education, Faculty of Education, Department of music teachers, researchers and field experts. is constitute. One of the biggest duties of us, the music educators, is to make the music teacher candidates we take with the aptitude test not only make them forget their field lessons, but also make them forget the lessons they learned at the Faculty of Education. Let's not forget that; Teaching is defined in the Basic Law of National Education as follows: "It is a specialization profession that takes on the education, training and related management duties of the state. Teachers are obliged to perform these duties in accordance with the objectives and basic principles of the Turkish National Education, have at least four years of graduation from a college with sufficient general culture, special field knowledge and pedagogical formation (Official Gazette, National Education Basic Law. et. al., 1979).

\section{References}

Bloom, S. B. (1976). Human Characteristics and School Learning. New York McGraw-Hill Book Company.

Çelenk, S. (1988). Attitudes of Education School Students towards Teaching Profession. Konya Selçuk University Institute of Social Sciences. Unpublished Doctoral Thesis.

Erden, M. (1995). Teacher candidates' attitudes towards teaching certificate courses. Hacettepe University Faculty of Education Journal.

Gordon, T. E. Ö. E. (2001). Effective Teacher Education. System Publications.

Güven, İ. (2004). Expectations from the Teacher for an Effective Teaching. National Education.

Okçabol, R., Akpınar, Y., Caner, A., Erktin, E., \& Gök, F. (2003). Teacher Training Research. Eğitim-Sen Publications. Ankara

Oktar, İ., \& Yazçayır. N. (2008). Effective Teacher Features According to Students. National Education.

Şahin, N. (2007). Attitudes of Arifiye Anatolian Teacher High School 3rd year students towards the teaching profession. Ankara. Hacettepe University Institute of Social Sciences. Unpublished Master Thesis.

Watson, D., Tregerthan G., \& Frank, J. (2006). Social Psychology: Science and Application. USA. Scott. Foresman and Company.

Worchel, S., \& Cooper, J. (1976). Understanding Social Psychology. Illinois. The Dorsey Press.

Wrihtsman, S. (1974). Social Psychology in the Seventies. California Brooks / Cole Publishing Company.

\section{Copyrights}

Copyright for this article is retained by the author(s), with first publication rights granted to the journal.

This is an open-access article distributed under the terms and conditions of the Creative Commons Attribution license which permits unrestricted use, distribution, and reproduction in any medium, provided the original work is properly cited. 